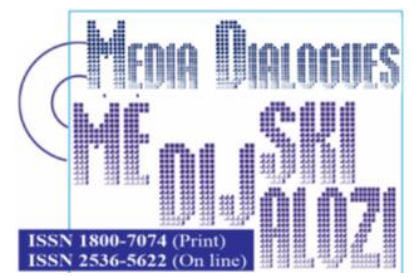

Ray, T. (2012), „Apple and Global Capital: The Case of the Ultimate Ideology Machine?", Media Dialogues / Medijski dijalozi, Vol. 13, No. 3, pp. 55-60.

\title{
Apple and Global Capital: The Case of the Ultimate Ideology Machine
}

\author{
Visiting Professor TAPAS RAY, \\ Doon University, School of Communication, \\ Dehradun, India
}

\begin{tabular}{|c|c|}
\hline $\begin{array}{l}A R T I C L E \\
I N F O\end{array}$ & $\begin{array}{c}\text { Received: December 20,2010 / } \\
\text { Accepted: February 27, } 2021\end{array}$ \\
\hline DOI & doi.org/10.14254/1800-7074/13-3/5 \\
\hline
\end{tabular}

Writing about "global culture" 15 years ago, Berger (1997) noted that the jetsetters Samuel Huntington associated with what he called "Davos culture" (after the annual World Economic Forum) were people at ease with such things as computers, cell phones, airline schedules and currency exchange. They "dress alike, exhibit the same amicable informality, relieve tensions by similar attempts at humor, and of cour- se most of them interact in English" (para 6). This is the picture of a smart and "successful" set, an elite, to which Berger refers as "yuppies" - short for young urban or upwardly-mobile professionals. The ways of this social group are imitated by aspirants to its status, and spread to the political elites, with which its members interact. "There is, as it were," Berger writes, "a yuppie internationale" (para 8).

In the same essay, he mentions three other fronts of cultural globalization, one of which involves "the internationalization of the Western intelligentsia, its values and ideologies" and which he calls the Faculty Club International (para 10). Though 
he does not mention it, anyone who has some familiarity with this "club", knows that laptops are as much part of its accoutrement as they are of the yuppies of "Davos culture".

Having said this, it is necessary to note that the world has not stood still in the last 15 years. Laptops are no longer so chic, and many of Berger's yuppies have abandoned them to embrace tablets instead.

Whether it's the tablet, the laptop, or even the rather less fashionable desktop, there is no denying that personal computers are "cool". And in the wake of the Arab revolutions - "Revolution 2.0" (Los Angeles Times, February 14, 2011) in the words of Wael Ghonim, the young Google executive whose Facebook page became a rallying site for opposition to the Mubarak regime in the heady days of the Egyptian revolution in late 2010 and early 2011 - these machines perhaps appear more godlike than ever. Although there is considerable distance between the "cool"ness of yuppiedom and the harsh realities of Tahrir Square, where blood was shed and lives were lost as protesters confronted pro-Mubarak elements armed with guns and knives, at least in the mass media, everything comes together in an undifferentiated mass of techno-utopian discourse.

We, however, can make a distinction between the "cool"ness of personal computers and their use value, which manifests itself in the technology's affordances and leads to concrete outcomes such as the "gathering" of Egyptian democrats on Ghonim's Facebook page. Much has been written about the second aspect - the political promise of the internet - over the years, and is not my focus here. I direct my attention, instead, to the "cool"ness of personal computing devices which, while being related to their affordances, is not reducible to these. I would like to argue that this aspect is the "subjective" side of personal computing, which Turkle (2005) noted while reporting the results of her ethnographic study of computer culture. She wrote:

Most considerations of the computer concentrate on the "instrumental computer, " on what work the computer will do. But my focus here is on something different, on the "subjective computer." This is the machine as it enters into social life and psychological deve- lopment, the computer as it affects the way that we think, especially the way we think about ourselves ...

Most considerations of the computer describe it as rational, uniform, constrained by logic. I look at the computer in a different light, not in terms of its nature as an "analytical engine," but in terms of its "second nature" as an evocative object, an object that fascinates, disturbs equanimity, and precipitates thought (p. 19) ...

(T)he computer, like a Rorschach inkblot test, is a powerful projective medium (p. 20).

Thus, the personal computer is, to its owner, much more than a machine to enhance productivity; it is something like an alter ego, being a medium on which she projects her own personality like inkblots in the (controversial) Rorschach psycho- 
logical test procedure, in which the subject is asked to state what shapes she sees in certain inkblots and her responses are believed, by some psychologists, to reveal the nature of her personality (The Rorschach Test, 2002, December 31).

This explains the strong bonds that develop between owners and their machines, and the emptiness and dislo- cation felt by many of them when their machines "crash" or are lost for one reason or another. Turkle quotes one such owner of a Palm PDA (personal digital assistant) as saying, "When my Palm crashed, it was like a death. It had my life on it ... I thought I had lost my mind" (p. 5).

This emotional attachment explains why decisions on buying these machines are not always determined by rational cost-benefit considerations. This is evident in the tablet computer market, which is dominated by Apple Computers with its iPad although there are many products from other manufacturers offering superior features, at least in some areas of the machines' operation, at lower prices. The Economist (December 02, 2011) noted that the Apple iPad enjoyed a near-monopoly over this market:

"(E)ssentially, there is no such thing as a tablet-computer business; what there is instead is a riproaring market for iPads-with some $32 \mathrm{~m}$ of them sold in the past 12 months alone. The iconic Apple product has nearly two-thirds of the market and rising, while a couple of dozen other tablet-makers squabble over the dwindling remainder. None has yet emerged as a credible challenger to the iPad."

The same article also notes that the first version of iPad had offered "a barely adequate specification" and in a year's time "rival tablets had entered the market and started running rings around the iPad - at least, in terms of performance and features, if not ease of use and elegance of design." A comparison between Amazon's Kindle Fire and the iPad, posted on the technology web site ZDNet the following day (Blue, 2011) noted certain superiorities of the former over the latter, and the vast differene in prices in favour of the Kindle.

The Economist puts the iPad's overwhelming success down to its initial lead in the market: "Apple pretty well invented the market segment, got the product broadly right with the initial iPad in April 2010, and then improved it with the iPad 2 in March 2011. As with any new electronics gadget, consumers invariably favour the one that has gained early momentum in the marketplace." ZDNet, on the other hand, attributes this success to its marketing strategy (Kendrick, 2011).

These may have elements of truth in them, but do not necessarily exhaust the reasons behind the iPad's dominant position. The main reason cited by entrepreneurs whom the business magaine Forbes (Berglas, 2011) interviewed when Apple's cofounder and CEO Steve Jobs (now deceased) took his third medical leave of absence from the company, relates to the evocative aspect of computers noted by Turkle. It had to do with the personality of Jobs, not the technical specifications of Apple products or other such "objective" factors. A Forbes article noted: 
To those who say, "Apple will continue developing its existing product lines for the immediate future and and has a well-stocked pipeline in place to keep the company running," entrepreneurs say, Poppycock!

Many Apple observers fail to see that the company Steve Jobs built never merely [was - TR] a business. It always was, and must always be in order to thrive, a corporate doppelgan- ger of its founder. This is why it has never been run successfully by anyone other that Jobs (e.g. John Sculley, Gil Amelio). Apple flourished because Jobs sensed, then produced, products that Apple addicts wanted in their lives. [Emphasis in original.]

This is why, to understand Apple as a cultural phenomenon, it is necessary to understand the personality of the late Jobs as it was projected to the world during his tenure as Apple's CEO. In this connection, it is useful to note the reference to "Apple addicts" in the Forbes article, which underlines a certain supra-rational attachment which many Apple users feel to their products and to the brand. Lam (2001) noted that the devotion of enthusiasts to Apple's Macintosh desktop computer had a strong religious dimension, and more recently Campbell and La Pastina (2010) have noted that the discourse on Apple's iPhone is imbued with religious imagery, with the iPhone being even called the "Jesus phone". When Jobs succumbed to pancreatic cancer, The New Statesman wrote:

There was undeniably something of the preacher about Steve Jobs. His product launches were quasi-religious events, at which sacred objects were revealed to an expectant crowd of initiates; some of whom had made a long pilgrimage to be there. Invariably wearing a shirt of clerical black, Jobs blurred the line between salesmanship and evangelism. Like a religious revivalist - or a demagogic politician - what he was selling was not just a consumer durable but a vision of life. In its allembracingness, Apple technology sought to offer people a solution to all their computing and communications needs. And the magic of the Apple name and logo allows devotees to ignore that the products themselves are often overpriced and underpowered (Jones, 2011).

According to The Wall Street Journal, the image of Jobs with which the public became familiar over the years, was a cultivated one. It wrote: "Even in his appearance, Mr. Jobs seemed to cultivate an image more like that of an artist than a corporate executive. In public, he rarely deviated from an outfit consisting of Levi's jeans, a black mock turtleneck and New Balance running shoes" (Kane and Fowler, 2011). This cultivated informality could be seen as a reference to Jobs' counter-cultural past, which (according to The New York Times) included taking LSD and traveling to India in the 1970s (Markoff, 2011), both of which were part of the expe-rience of many Westerners of the "Sixties" generation who wished to reject the tech-nological rationality of the West.

If we note the widely accepted view that Christ was something of a rebel in his time, the religious overtones associated with many users' attitude to their Apple pro- 
ducts (an accentuation, it may be said, of the trope of "technological sublime"), and Jobs' constant (indirect) reminder of his countercultural past, appear to be mutually resonant parts of the same message. This message, made explicit through the television advertisement which marked the launch of the Macintosh desktop in 1984, was one of opposition to "the establishment."

In that advertisement, which had clear references to the classic 1982 film Bladerunner and George Orwell's novel 1984 (Khalili-Mahani, 2011), the establishment was clearly if indirectly identified as IBM Corporation, at the time the dominant force in the computer market. Later, the establishment remained undefined, and as a floating signifier, has attached itself metonymically to the capitalist system as a whole.

And herein lies a certain difficulty; for not only is Apple - obviously - part of this system, it is arguably an eminent member of the system. In May 2011, Bloomberg was reporting (Culpan, 2011) that the Apple brand had become the highest valued in the world at $\$ 153.3$ billion, exceeding Google's $\$ 111.5$ billion by a large margin. According to at least one market analysis firm, which has been quoted by The New York Times, Apple is now the largest maker of personal computers in the world (Wingfield, 2012).

Not only this. As Chait (October 06, 2011) noted in the New York Magazine, at a time when the legitimacy of global finance capital was being challenged in its own front yard by the Occupy Wall Street movement in the wake of the economic crisis that had engulfed the West as a result of wrongdoings by this sector of global capital, Apple's popularity was being exploited by some commentators to re-legitimize it, as it were. They were holding up Apple's successful business practices as an argument in favour of capitalism, and implicitly claiming that it was in the same league as finance capital and internet pornography, on the plea that "markets are very democratic-everybody gets to decide for himself what he values". In other words, in spite of e- verything, capitalism is "cool".

If we return to Turkle's formulation of the evocative nature of computers, we can see that all this makes the admiring user of Apple products and the late Steve Jobs - who sees herself in these products and in the associated imagery of Jobs - the ideal subject of ideology. For, while the work of ideology depends on its own invisibility, Apple and Jobs achieve this in the most perfect way: while being an ardent admirer of a leading representative of global capital in its hour of crisis, the Apple aficionado sees herself as an independent soul, almost a rebel against "the establishment". 


\section{REFERENCES}

Berger, P.L. (1997, Fall), „Four faces of global culture“, In The National Interest, No. 49, pp. 23-29, via Academic OneFile, Gale, through University of Delaware Library.

Berglas, S. (2011), „Steve Jobs: The Human Rorschach“(Inkblot), Forbes, February 13.

Blue, V. (2011), Great Debate postmortem: Kindle Fire vs. Ipad, December 03.

Campbell, H., and La Pastina, A. (2010), „How the iPhone became divine: New media, religion and the intertextual circulation of meaning", New Media \& Society, Vol. 12, No. 7, pp. 1191-1207.

Chait, J. (2011), Steve Jobs, Occupy Wall Street, and the capitalist ideal, The New York Magazine, October 06.

Culpan, T. (2011), „Apple brand value at $\$ 153$ billion overtakes Google for top spot", Bloomberg, May 08.

Jones, N. (2011), „Steve Jobs: Technological messiah“, The New Statesman, October 07.

Kane, Y.I., Fowler, G.A. (2011), Steven Paul Jobs, 1955-2011: Apple co-founder transformed technology, media, retailing and built one of the world's most valuable companies, The Wall Street Joiurnal, October 06.

Kendrick, J. (2011), „Why consumers won’t buy tablets (unless they're i-Pads)“, August 17.

Khalili-Mahani, N. (2011), ,iPhenomenon: Capitalizing on difference through screens of Apple“, Communicationspace, October 06.

Lam, P-Y. (2001, Summer), „May the force of the operating system be with you: Macintosh devotion as implicit religion", Sociology of Religion, Vol. 62, No. 2, pp. 243-262.

Markoff, J. (2011), „Apple's visionary redefined digital age“, The New York Times Reprints, October 05.

The Economist (2011), „Tablet computers: Difference Engine: The iPad's third coming", December 02.

The Los Angeles Times (2011), „Wael Ghonim, Google exec, says Egypt's revolution is 'like Wikipedia'“, February 14.

The Rorschach Test (2002), Encyclopedia of Psychology, December 31.

Turkle, S. (2005), „The second self: Computers and the human spirit“, The MIT Press, Cambridge, MA (USA).

Wingfield, N. (2012), „Apple becomes world's biggest maker of computers“, The New York Times, January 30. 